\title{
EUTROPIICHTHYS CETOSUS, A NEW RIVERINE CATFISH (TELEOSTEI: SCHILBEIDAE) FROM NORTHEASTERN INDIA
}

\author{
Heok Hee $\mathrm{Ng}^{1}$, Lalramliana ${ }^{2}$, Samuel Lalronunga ${ }^{3}$ \& Lalnuntluanga ${ }^{4}$ \\ ${ }^{1}$ c/o Lee Kong Chian Natural History Museum, National University of Singapore, 6 Science Drive 2, \#03-01, Singapore \\ 117546 \\ ${ }^{2}$ Department of Zoology, Pachhunga University College, Aizawl, Mizoram 796001, India \\ ${ }^{3,4}$ Department of Environmental Science, Mizoram University, Aizawl, Mizoram 796004, India \\ ${ }^{1}$ heokhee.ng@gmail.com (corresponding author), ${ }^{2}$ Irl_zoo@yahoo.co.in, ${ }^{3}$ samuellrna@gmail.com, \\ ${ }^{4}$ tluanga_249@rediffmail.com
}

\begin{abstract}
Eutropiichthys cetosus, a new species of schilbeid catfish is described from the Kaladan River drainage in Mizoram, northeastern India. It can be distinguished from congeners in having a combination of the following characters: $49-52$ total vertebrae, snout moderately rounded in lateral and slightly trilobed in dorsal views, fleshy narial flap not extending medially much past medial margin of naris, mouth rictus reaching vertical through middle of orbit, 25-35 rakers on the first gill arch, rough anterior edge of pectoral spine, 13-15 branched pectoral-fin rays, body depth at anal-fin origin 17.5-23.5 \% SL, 43-49 branched anal-fin rays, and caudal peduncle depth 7.8-8.6 \% SL. A revised key to the genus is provided.
\end{abstract}

Keywords: Kaladan River drainage, Mizoram, Ostariophysi, Siluriformes.

DOI: http://dx.doi.org/10.11609/JoTT.o3883.6073-81 | ZooBank: urn:Isid:zoobank.org:pub:DF18D869-2259-4E60-90E6-151111A908A4

Editor: Neelesh Dahanukar, IISER, Pune, India.

Date of publication: 26 July 2014 (online \& print)

Manuscript details: Ms \# 03883 | Received 17 December 2013 | Final received 18 June 2014 | Finally accepted 06 July 2014

Citation: Ng, H.H., Lalramliana, S. Lalronunga \& Lalnuntluanga (2014). Eutropiichthys cetosus, a new riverine catfish (Teleostei: Schilbeidae) from northeastern India. Journal of Threatened Taxa 6(8): 6073-6081; http://dx.doi.org/10.11609/JoTT.03883.6073-81

Copyright: @ $\mathrm{Ng}$ et al. 2014. Creative Commons Attribution 4.0 International License. JoTT allows unrestricted use of this article in any medium, reproduction and distribution by providing adequate credit to the authors and the source of publication.

Funding: SLRN is funded by an MZU-UGC Research Scholar's Fellowship.

Competing Interest: The authors declare no competing interests.

Author Contribution: LRL, SLRN and LNT collected the material, provided habitat photos and edited the manuscript. HHN gathered the data and drafted the manuscript.

Author Details: HEOK HEE NG works on the taxonomy and phylogeny of Asian catfishes, particularly those of the superfamily Sisoroidea. LALRAMLIANA is an Assistant Professor and his field of specialization is fish and fisheries. He is presently engaged in molecular characterization and phylogeny of freshwater fishes of Mizoram. SAMUEL LALRONUNGA is a research scholar, registered for a PhD degree. He is working on diversity of fishes of Mizoram, northeastern India and their phylogenetic analysis. LALNUNTLUANGA is an Associate Professor and his field of specialization is biodiversity. He is presently engaged in taxonomy and systematics of freshwater organisms of Mizoram.

Acknowledgements: We thank the following for access to material under their care: Mark Sabaj Pérez (ANSP), David Catania (CAS, CAS-SU), Karsten Hartel (MCZ), Douglas Nelson (UMMZ), Lynne Parenti (USNM), and Kelvin Lim (ZRC). Funding for SLRN from MZU-UGC Research Scholars' Fellowship is also acknowledged here.

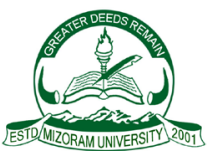




\section{INTRODUCTION}

The Old World catfish family Schilbeidae is a moderately diverse group comprising 65 species in 14 genera (Ferraris 2007; Ferraris \& Vari 2007; Ng \& Vidthayanon 2011), of which approximately half (32 species) is known from Asia. The genus Eutropiichthys Bleeker, 1862, comprises medium-sized riverine species known from the Salween River drainage in western Thailand, westwards to the Indus River drainage in Pakistan. The genus has been recently revised (Ferraris \& Vari 2007) and it comprises five species: $E$. britzi Ferraris \& Vari, 2007 from the Irrawaddy River drainage in Myanmar; E. burmannicus Day, 1877 from the Irrawaddy and Sittang river drainages in Myanmar, and the Salween River drainage in Myanmar and western Thailand; E. murius (Hamilton, 1822) from the Ganges-Brahmaputra River system in Bangladesh, India and Nepal; E. salweenensis Ferraris \& Vari, 2007 from the lower Salween River drainage in western Thailand; and E. vacha (Hamilton, 1822) from the Indus River drainage in Pakistan, Ganges-Brahmaputra River system in Bangladesh, Bhutan, India and Nepal, Mahanadi River drainage in India, and Surma-Meghna River system in Bangladesh.

During recent ichthyological surveys of the Kaladan River drainage in Mizoram, India, the second and third authors collected specimens of Eutropiichthys. Attempts to identify the specimens and detailed comparison of this material with congeners, revealed it to be a new species, described herein as Eutropiichthys cetosus. A revised key to the genus incorporating the results of this study is also provided.

\section{MATERIAL AND METHODS}

Measurements were made point to point with dial calipers and data recorded to tenths of a millimeter. Counts and measurements were made on the left side of specimens whenever possible. Vertebrae and medianfin rays were counted from radiographs, while pairedfin rays were counted under a binocular dissecting microscope. Subunits of the head are presented as proportions of head length $(\mathrm{HL})$. Head length and measurements of body parts are given as proportions of standard length (SL). Measurements and counts follow those of Ferraris \& Vari (2007) with the exception of the gill raker counts, which are expressed as epibranchial (upper limb)+ceratobranchial (lower limb)=total, and the additions of the head depth (measured at the base of the supraoccipital process), snout to pectoral-fin spine base (measured from the tip of the snout to the base of the pectoral-fin spine), dorsal-fin base length (measured from the base of the dorsal-fin spinelet to the base of the last dorsal-fin ray) and the body depth at dorsal-fin origin (measured immediately anterior to the base of the first dorsal-fin spinelet). Numbers in parentheses following a particular meristic count are the number of individuals with that count. Asterisks after meristic counts indicate values for holotype. Material examined in this study is deposited in the following institutions: Academy of Natural Sciences of Drexel University, Philadelphia (ANSP); California Academy of Sciences, San Francisco (CAS, CAS-SU); Museum of Comparative Zoology, Harvard University, Cambridge (MCZ); Pachhunga University College Museum of Fishes, Aizawl (PUCMF); University of Michigan Museum of Zoology, Ann Arbor (UMMZ); National Museum of Natural History, Smithsonian Institution, Washington DC (USNM); and Lee Kong Chian Natural History Museum, Singapore (ZRC).

\section{Eutropiichthys cetosus sp. nov.} (Images 1, 2a)

urn:Isid:zoobank.org:act:35BB016E-824F-4B4E-89E4-6FF2E71A13DD

\section{Type material}

Holotype: PUCMF13024, 16.viii.2011, 121.8mm SL, $22^{\circ} 23^{\prime} 1.4^{\prime \prime} \mathrm{N} \& 92^{\circ} 57^{\prime} 39.3^{\prime \prime} \mathrm{E}$, vicinity of Kawlchaw Village, Lawngtlai District, Mizoram, India, coll. S. Lalronunga.

Paratypes: PUCMF13025 (5), 91.4-127.7 mm SL, data as for holotype.

\section{Diagnosis}

Eutropiichthys cetosus can be distinguished from all congeners, except for E. burmannicus, in having more rakers (25-35 vs. 15-20) on the first gill arch. It differs from E. burmannicus in the shape of the snout in both lateral (moderately rounded in $E$. cetosus sp. nov. vs. distinctly pointed in E. burmannicus; Image 2) and dorsal (slightly trilobed in $E$. cetosus sp. nov. vs. acutely angular in $E$. burmannicus; Images 2, 3) views, a deeper head relative to its length (68.7-77.1\% HL vs. $65.4-67.5 \% \mathrm{HL}$ ), fewer branched pectoral-fin rays (13-15 vs. $15-17$, rarely 15$)$, and a more slender body (depth at dorsal-fin origin 19.2-23.5\% SL vs. $23.7-25.3 \% S L$; depth at anal-fin origin 17.5-23.5\% SL vs. $23.2-26.3 \% \mathrm{SL}$; compare Images 1 and 3 ). The following unique combination of characters serves to further distinguish $E$. cetosus sp. nov. from congeners: 49-52 total vertebrae, fleshy narial flap not extending medially much past medial margin of naris, 


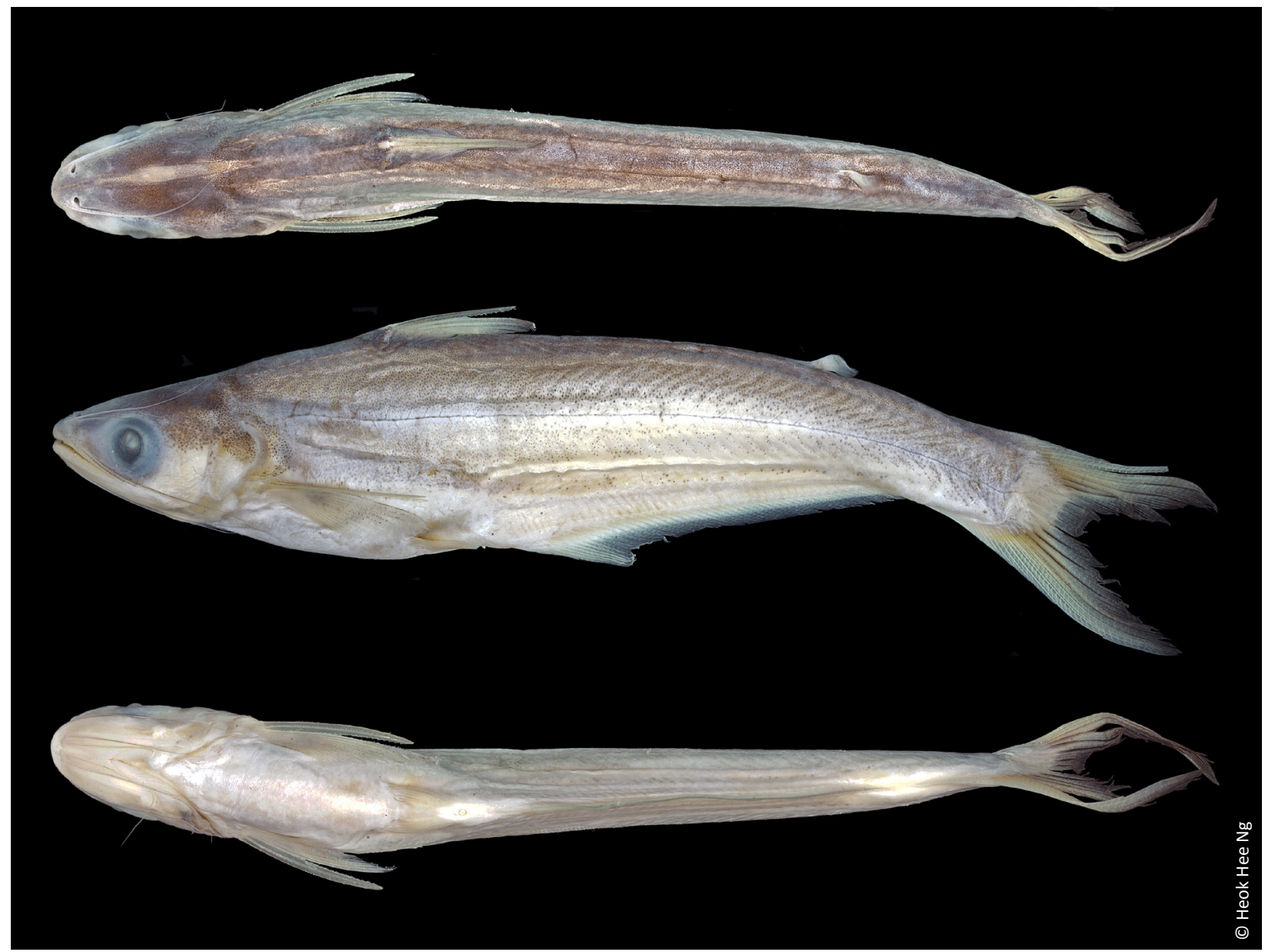

Image 1. Eutropiichthys cetosus sp. nov., PUCMF 13024, holotype, 121.8mm SL, India: Mizoram, vicinity of Kawlchaw Village.

mouth rictus reaching vertical through middle of orbit, rough anterior edge of pectoral spine, 43-49 branched anal-fin rays, and caudal peduncle depth $7.8-8.6 \% \mathrm{SL}$.

\section{Description}

General shape and appearance as in Image 1. Biometric data in Table 1. Body elongate, compressed. Body depth greatest at dorsal-fin origin. Dorsal profile of body nearly straight from rear of head to dorsal-fin origin and gently convex between posterior terminus of dorsal-fin base and caudal-fin origin. Ventral profile of body convex to anal-fin origin, then straight along base of anal fin. Vent located slightly anterior of anal-fin origin. Lateral line complete, midlateral, and extending onto basal fleshy portion of dorsal lobe of caudal fin, with short secondary branches extending obliquely above and below entire length of main portion of system. Total vertebrae 49 (1), 50 (2), 51 (2) or $52 *(1)$.

Head compressed along entire length, subacute from lateral view and linear from dorsal view; depth much greater than width. Opercular opening broad, extending from horizontal through anterior limit of lateral line to vertical through middle of pupil. Opercular membranes not connected to isthmus. Posteroventral margin of operculum with posteriorly directed, fleshy lobe; posterior portion of lobe rounded.

Anteriormost portion of snout subacute in lateral view. Snout margin slightly trilobed from dorsal view (Image 2a), but with lobes poorly defined. Anterior naris round, anteriorly directed, and located on anterior margin of snout. Posterior naris rounded. Posterior naris located slightly posterodorsal and medial to anterior naris. Width of posterior naris approximately equal to one-half of internarial distance. Anterior margin of naris with convex flap of skin extending medial of medial margin of naris for distance less than transverse extent of opening of naris.

Eye positioned laterally, visible from both dorsal and ventral views; middle of eye positioned slightly below horizontal through middle of vertical extent of head 


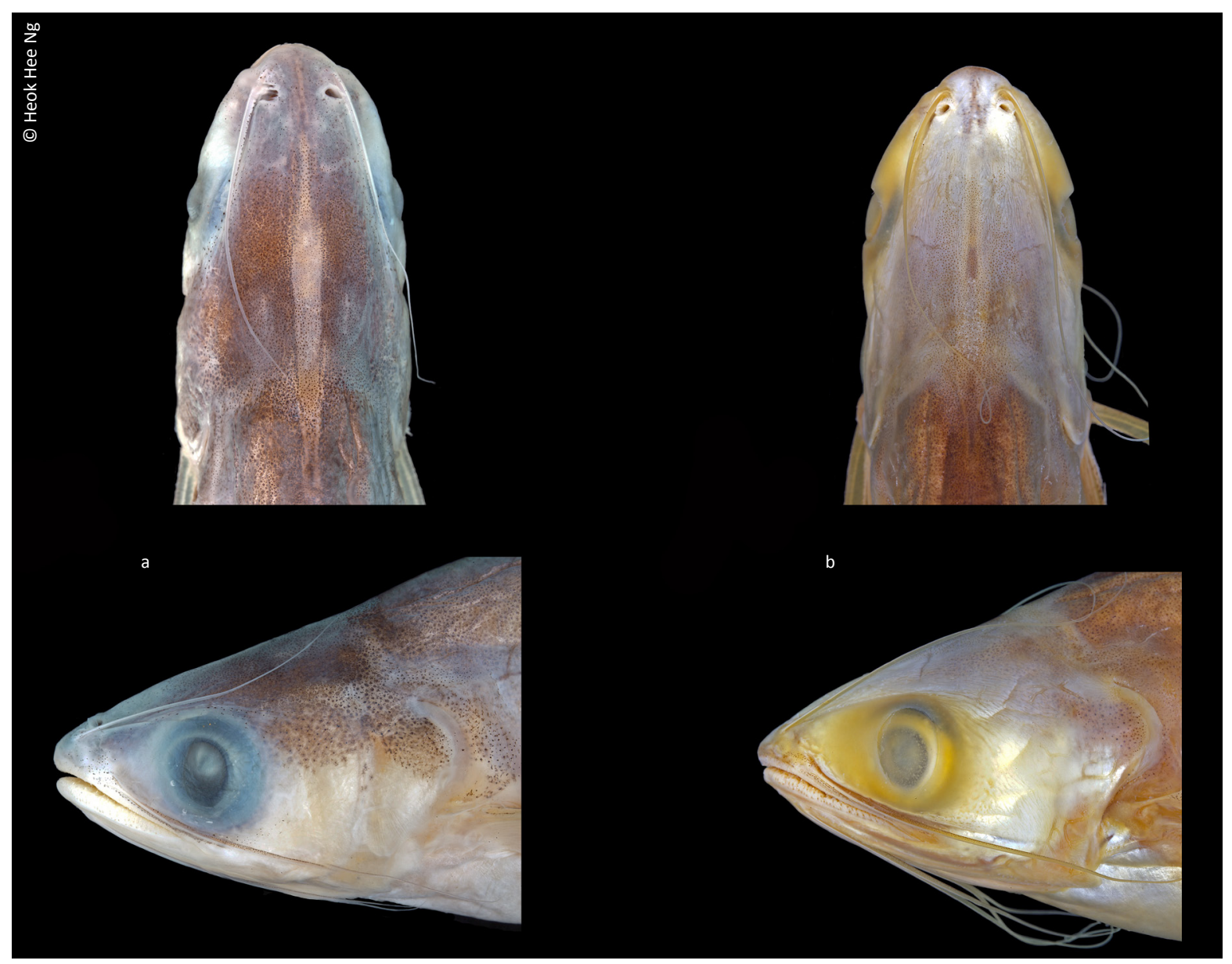

Image 2. Dorsal and lateral views of heads of: (a) - Eutropiichthys cetosus sp. nov., PUCMF 13024, holotype, 121.8mm SL; (b) - E. burmannicus, ZRC 43514, 121.8mm SL, showing differences in snout shape. Images not to scale.

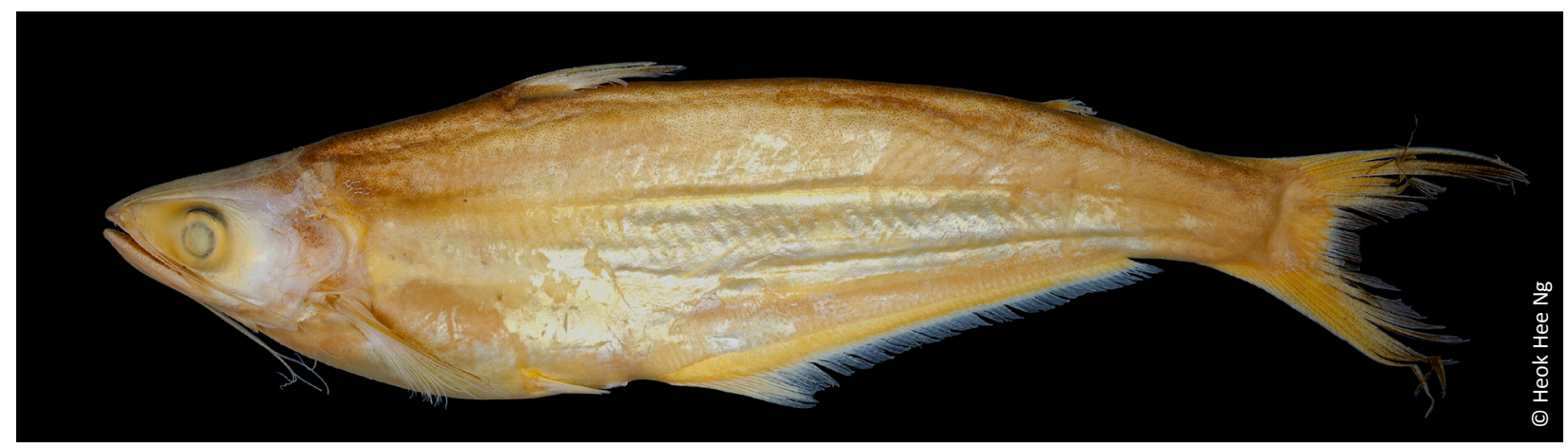

Image 3. Eutropiichthys burmannicus, ZRC 43514, 125.7mm SL; Myanmar: Mandalay.

and distinctly below horizontal through anterior naris. Anterior and posterior portions of eye covered laterally by connective tissue (adipose eyelid), but with ovoid, vertically elongate opening positioned lateral to pupil.

Mouth terminal, with opening large and posteroventrally angled. Posterior terminus of gape at vertical through middle of pupil. Lower jaw slightly shorter than upper. Premaxillary tooth plate crescentic. Teeth on tooth plate slender, conical, and depressible, with approximately seven irregular rows at symphysis that progressively reduce to three or four irregular rows laterally. Teeth on posteromedial portion of tooth plate 
Table 1. Biometric data for Eutropiichthys cetosus sp. nov. $(n=6)$.

\begin{tabular}{|c|c|c|c|}
\hline & $\begin{array}{c}\text { Holotype } \\
\text { PUCMF } 13024 \\
\end{array}$ & Range* & Mean $\pm S D$ \\
\hline Standard length $(\mathrm{mm})$ & 121.8 & $91.4-127.7$ & \\
\hline \multicolumn{4}{|l|}{$\% S L$} \\
\hline $\begin{array}{l}\text { Snout to dorsal-fin } \\
\text { origin }\end{array}$ & 35.2 & $32.4-35.2$ & $33.4 \pm 1.1$ \\
\hline Snout to anal-fin origin & 47.9 & $45.0-48.4$ & $46.9 \pm 1.2$ \\
\hline $\begin{array}{l}\text { Snout to pelvic-fin } \\
\text { insertion }\end{array}$ & 36.3 & $36.3-38.4$ & $37.3 \pm 0.7$ \\
\hline $\begin{array}{l}\text { Snout to pectoral-fin } \\
\text { spine base }\end{array}$ & 22.4 & $20.4-22.6$ & $21.8 \pm 0.9$ \\
\hline $\begin{array}{l}\text { Length of dorsal-fin } \\
\text { base }\end{array}$ & 8.0 & $7.2-8.6$ & $7.9 \pm 0.5$ \\
\hline Dorsal-spine length & 14.7 & $14.7-16.8$ & $15.9 \pm 0.8$ \\
\hline Length of anal-fin base & 39.7 & $39.1-42.8$ & $41.2 \pm 1.6$ \\
\hline $\begin{array}{l}\text { Length of first pelvic- } \\
\text { fin ray }\end{array}$ & 8.0 & $7.3-9.1$ & $8.3 \pm 0.8$ \\
\hline $\begin{array}{l}\text { Length of first pectoral- } \\
\text { fin ray }\end{array}$ & 18.0 & $18.0-21.7$ & $18.8 \pm 1.0$ \\
\hline $\begin{array}{l}\text { Length of pectoral-fin } \\
\text { spine }\end{array}$ & 17.0 & $16.7-19.7$ & $17.6 \pm 1.1$ \\
\hline $\begin{array}{l}\text { Length of dorsal } \\
\text { principal caudal-fin ray }\end{array}$ & 25.4 & $21.5-27.3$ & $24.4 \pm 2.3$ \\
\hline $\begin{array}{l}\text { Body depth at dorsal- } \\
\text { fin origin }\end{array}$ & 21.3 & $19.2-23.5$ & $21.5 \pm 1.7$ \\
\hline $\begin{array}{l}\text { Body depth at anal-fin } \\
\text { origin }\end{array}$ & 20.4 & $17.5-23.5$ & $21.1 \pm 2.1$ \\
\hline $\begin{array}{l}\text { Body width at pectoral- } \\
\text { fin insertion }\end{array}$ & 11.3 & $10.5-12.6$ & $11.5 \pm 0.7$ \\
\hline Caudal-peduncle depth & 8.1 & $7.8-8.6$ & $8.3 \pm 0.3$ \\
\hline Head length & 22.6 & $20.4-22.6$ & $21.3 \pm 0.7$ \\
\hline \multicolumn{4}{|l|}{$\% \mathrm{HL}$} \\
\hline Head depth & 68.7 & $68.7-77.1$ & $71.8 \pm 2.9$ \\
\hline Interorbital distance & 27.3 & $27.3-31.2$ & $29.4 \pm 1.4$ \\
\hline
\end{tabular}

* Individual measurements of paratypes provided in Appendix 1.

larger than remaining teeth on that plate. Outermost teeth of upper jaw exposed laterally when mouth closed. Accessory premaxillary tooth plate extends from posterolateral margin of premaxillary tooth plate nearly to rear of gape. Teeth on accessory plate arranged in four or five irregular rows, with teeth largest medially and progressively decreasing in size laterally. Lateral teeth on accessory patch comparable in size to smallest teeth on premaxilla. Palatal tooth patch in form of parabolic arch extending posteriorly from midline to slightly past posterior terminus of accessory tooth patch. Anterior and lateral margins of palatal tooth patch closely applied to, but slightly separated from, posterior margin of premaxillary tooth patch and medial margins of accessory tooth patch. Teeth of palatal tooth patch slender and conical, with teeth of medial portion of patch largest and remaining teeth becoming progressively smaller posterolaterally. Largest teeth on palate comparable in size to largest teeth on premaxilla. Dentary tooth plate parabolic with slender, conical teeth covering dorsal surface and extending onto lateral surface of dentary. Teeth on lateral surface of dentary visible in closed mouth. Teeth along medial portion of anterior one-half of dentary largest with remaining teeth becoming progressively smaller. Largest teeth on dentary approximately equal in size to largest teeth on premaxilla. Dentary with seven or eight irregular rows of teeth along entire length of tooth patch. Gill rakers on outer face of first arch $7+18=25^{*}(1), 7+20=27$ (2), $9+20=29(1), 10+21=31$ (1) or $11+24=35$ (1).

Barbels in four pairs. All barbels rest in shallow groove in skin, at least basally. Nasal barbel threadlike and extending posteriorly from lateral margin of posterior naris to beyond vertical through posterior limit of opercle. Maxillary barbel extends from posterior of anterior naris to slightly past middle of pectoral fin. Mandibular barbels in two pairs; barbel bases originate in transverse row at level of posterior naris. Medial and lateral mandibular barbels extend posteriorly to transverse through pectoral-fin base.

Dorsal-fin origin located at anterior one-third of SL. Dorsal-fin base short, about equal to length of snout. Dorsal fin slightly smaller than pectoral fin; segmented rays preceded by spinelet and sharply pointed, slender spine. Spine smooth anteriorly and with 7-20 very fine serrations along distal one-half of posterior margin, with irregular surface but without distinct serrations along basal portion of that margin. Fin margin straight with rays becoming progressively shorter posteriorly; length of last ray about one-half that of first ray. Dorsal-fin rays II,7(6). Adipose fin small and oar-shaped, located above posterior one-third of anal-fin base. Caudal fin deeply forked, lobes pointed and nearly symmetrical. Outer principal rays about three times the length of middle rays. Principal caudal-fin rays $i, 7,8, i(6)$. Anal-fin origin located markedly anterior to vertical through middle of SL. Anal-fin base long. Anal-fin margin slightly concave anteriorly, nearly straight posteriorly; posterior ray shortest. Last fin ray without membranous connection to caudal peduncle. Anal-fin rays v,43 (1), v,45(2), v,46 (1), v,47*(1), or v,49(1).

Pelvic fin small, its length only slightly more than one-half that of pectoral fin. Pelvic-fin insertion located slightly posterior of vertical through dorsal-fin origin. Adpressed fin extending ventral of anus with tip of fin reaching slightly past urogenital pore but falling short of anal-fin origin. Pelvic-fin rays i,5 (6). Pectoral fin triangular, first branched ray longest. Tip of adpressed extends posteriorly to beyond vertical through terminus 


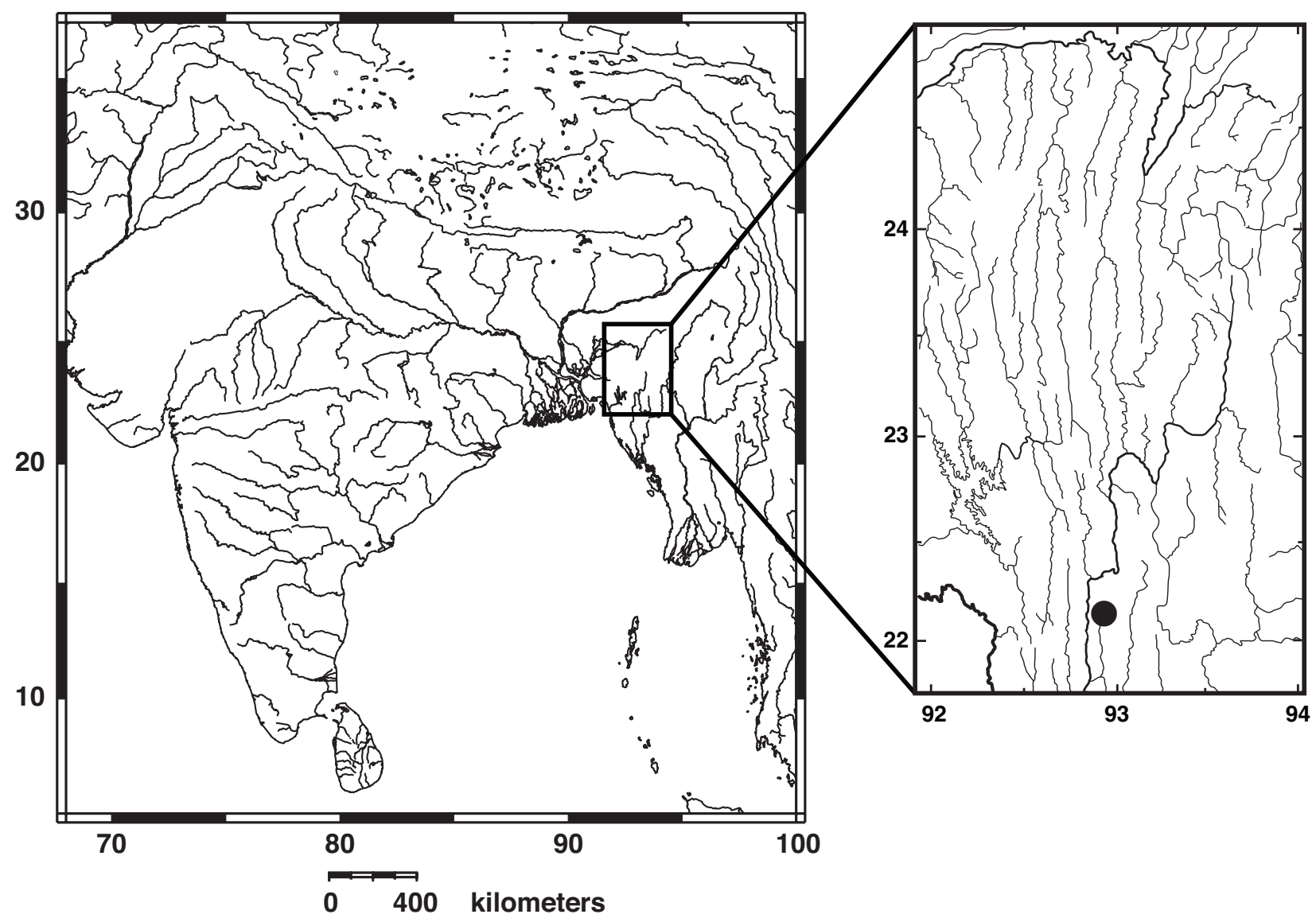

Figure 1. Map showing type locality of Eutropiichthys cetosus sp. nov.

of dorsal-fin base. Pectoral-fin spine slender, but more robust than that of dorsal fin; with fine roughened ridge anteriorly and 12-23 retrorse serrations on distal twothirds of posterior margin. Pectoral-fin rays $I, 13, i^{*}(3)$, $\mathrm{I}, 14, \mathrm{i}(1)$ or $\mathrm{I}, 15$ (2).

\section{Coloration}

In 70\% ethanol: Body variably brown dorsally, pale gray on lateral and ventral surfaces, with melanophores decreasing in density ventrally. Dorsal half of head brown, ventral half pale gray. Dorsal and caudal fins unpigmented other than for diffuse, marginal, dark band. Adipose, anal and pelvic fins unpigmented. Pectoral fin with scattered melanophores on interradial membranes, particularly on dorsal half of fin; remainder of fin unpigmented. Maxillary and lateral mandibular barbels dusky on dorsal surfaces. Nasal barbel and medial mandibular barbel unpigmented.

\section{Habitat and Distribution}

This species is currently known only from the Kaladan River drainage in southern Mizoram (Fig. 1), although it highly likely to occur in parts of the river drainage that flow through Myanmar as well. The Kaladan River (also known as Chhimtuipui in Mizoram) originates from the Chin Hills in Myanmar and debouches into the Bay of Bengal near Sittwe in Myanmar. The specimens were

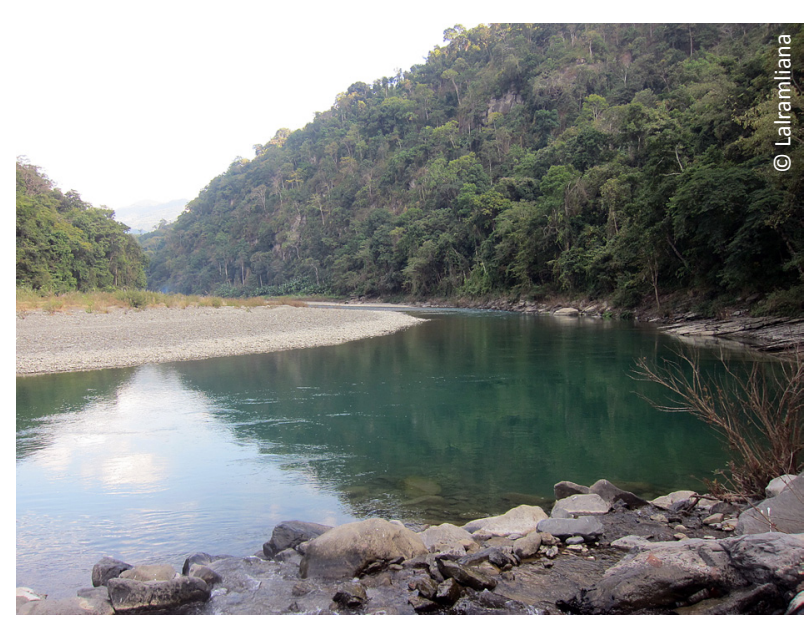

Image 4. Type locality of Eutropiichthys cetosus sp. nov. 
collected from a clear, slow and moderate flowing river with a depth of 1-4 m (Image 4).

\section{Etymology}

The specific epithet comes from the adjectival form of the Latin 'cetus', meaning a large sea animal (commonly referred to a whale). This name is used in allusion to the numerous gill rakers of this species, which are reminiscent of baleen in baleen whales.

\section{DISCUSSION}

Eutropiichthys cetosus sp. nov. is morphologically similar to E. burmannicus, but can be distinguished from it by the characters as outlined in the diagnosis.

Besides the higher number of gill rakers in the first gill arch (as outlined in the diagnosis), E. cetosus sp. nov. is further distinguished from $E$. britzi in having a lesser number of vertebrae (49-52 vs. 52-54), a more slender body (depth at anal-fin origin 17.5-23.5\% SL vs. 23.3-27.1 \% SL) and caudal peduncle (depth 7.88.6 \% SL vs. 9.2-11.0 \% SL), and from E. murius (we follow Ferraris \& Vari 2007 in considering Pachypterus melanurus Swainson, 1839 a junior synonym) in having a higher number of vertebrae (49-52 vs. 43-45), a more posteriorly-extended gape (mouth rictus reaching vertical through middle of orbit vs. anterior orbital margin), a rough (vs. smooth) anterior edge of the pectoral spine, more branched pectoral- (13-15 vs. 11 or 12 ) and anal-fin rays (43-49 vs. $32-37$ ). In both $E$. britzi and $E$. murius, the fleshy flap along the anterior margin of the posterior naris proximally reaches beyond the medial margin of the naris by a distance equal to, or greater than, the transverse dimension of the posterior naris (vs. proximally reaching beyond the medial margin of the naris for a distance distinctly less than the transverse length of the posterior naris in $E$. cetosus sp. nov.). We follow Ferraris \& Vari (2007) in considering Pseudeutropius murius batarensis a junior synonym of E. murius, although they raised the possibility that the two specimens on which Shrestha's (1981) description of $P$. murius batarensis is based might instead be a species of Clupisoma. Without directly examining the type specimens of $P$. murius batarensis, we are unable to verify Ferraris \& Vari's hypothesis.

Eutropiichthys cetosus sp. nov. further differs from $E$. salweenensis in having a lesser number of vertebrae (49-52 vs. 52-54), a rough (vs. smooth) anterior edge of the pectoral spine, a more slender caudal peduncle (depth 7.8-8.6\% SL vs. 9.2-10.2) and from E. vacha (we follow Ferraris \& Vari 2007 in considering Pachypterus punctatus Swainson, 1839 a junior synonym) in the shape of the snout in both lateral (moderately rounded in E. cetosus vs. distinctly pointed in E. vacha) and dorsal (slightly trilobed in $E$. cetosus sp. nov. vs. acutely angular in E. vacha) views, and a more slender caudal peduncle (depth 7.8-8.6\% SL vs. 8.8-10.4\% SL).

The Kaladan River, lying between the Surma-Meghna River system in the north and the Chindwin-Irrawaddy River drainage in the east, harbours high endemism of hillstream fish fauna (Anganthoibi \& Vishwanath 2010; Dishma \& Vishwanath 2012; Lokeshwor \& Vishwanath 2012; Ng et al. 2013). Our discovery of a new fish species typically found in the main channels of larger rivers in this drainage suggests that a similar level of endemism may also be found in the non-hillstream freshwater ichthyofauna of the Kaladan River drainage.

\section{Comparative material}

Eutropiichthys burmannicus: CAS 88816 (1), 113.7 $\mathrm{mm}$ SL, Bago Region, Sittaung River at Taungoo, 18055'N \& 96025'E. ZRC 43514 (5), 108.7-193.3 mm SL, Myanmar: Mandalay Region, market in Mandalay (Image 3). Additional data from Ferraris \& Vari (2007).

E. britzi: CAS-SU 39868 (7), 186.0-229.0 mm SL, Myanmar: Sagaing Region, market at Monywa, on Chindwin River. Additional data from Ferraris \& Vari (2007).

E. murius: UMMZ 208724 (3), 93.3-108.1 mm SL; Bangladesh: Sylhet District, Sharigat bazaar, $35 \mathrm{~km} \mathrm{NE}$ of Sylhet on Sylhet-Shillong highway, $25^{\circ} 4^{\prime} \mathrm{N} \& 92^{\circ} 7^{\prime} \mathrm{E}$. UMMZ 244742 (1), 86.0mm SL, India: West Bengal State, Mansai River, $1 \mathrm{~km}$ after Amtala on Jalpaiguri-

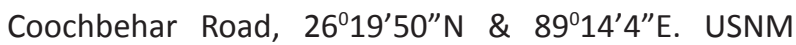
316716 (2), 101.0-102.89 mm SL, India: Uttar Pradesh State, Kanpur, $26^{\circ} 28^{\prime} \mathrm{N} \& 88^{\circ} 30^{\prime} \mathrm{E}$. Additional data from Ferraris \& Vari (2007).

E. salweenensis: CAS 76261 (holotype), 124.0mm SL; Thailand: Mae Hong Son Province, Salween River $20 \mathrm{~km}$ upriver from Mae Sam Laep. Additional data from Ferraris \& Vari (2007).

E. vacha: ANSP $85763(1), 132.7 \mathrm{mmSL}$, India: Mumbai. CAS 61841 (2), 88.8-135.9 mm SL, India: Odisha State,

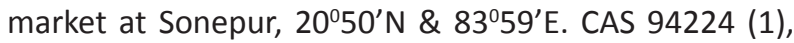
$212.5 \mathrm{~mm} \mathrm{SL}$, India: Odisha State, Hirakud Reservoir or Sambalpur market. MCZ 4257 (1), 113.7mm SL, UMMZ 238802 (1), 144.0mm SL; India: West Bengal State, Kolkata. UMMZ 208293 (1), 178.8mm SL, Bangladesh: Comilla District, Meghna River, downstream from Gumti

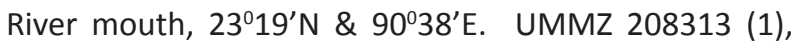
141.7mm SL, Bangladesh: Comilla District, Meghna River, 
Key to the species of Eutropiichthys (modified from Ferraris \& Vari 2007)

1. Anal fin with 32-37 branched rays; pectoral fin with 11 or 12 branched rays (Ganges-Brahmaputra river system in Bangladesh,

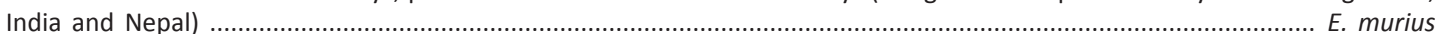
Anal fin with 43-55 branched rays; pectoral fin with 13-17 branched rays ................................................................... 2

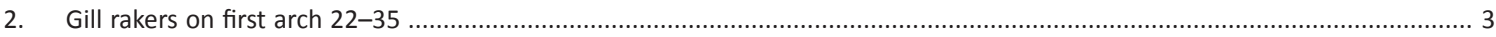

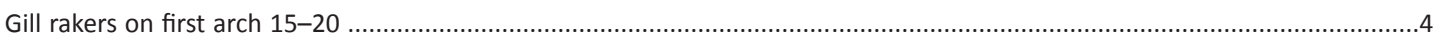

3. Snout distinctly pointed and acutely angular when viewed laterally and dorsally respectively; head depth $65.4-67.5 \% \mathrm{HL}$; body depth at dorsal-fin origin 23.6-25.3\% SL (Irrawaddy and Sittang river drainages in Myanmar; Salween River drainage in Myanmar and western Thailand) ............................................................................................................... E. burmannicus Snout moderately rounded and slightly trilobed when viewed laterally and dorsally respectively; head depth 68.7-77.5\% $\mathrm{HL}$; body depth at dorsal-fin origin 19.2-23.5\% SL (Kaladan River drainage in India and possibly Myanmar) ......... E. cetosus sp. nov.

4. Fleshy narial flap extending medially past medial margin of naris, nearly reaching midline of head (Irrawaddy River drainage in

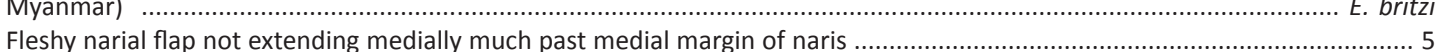

5. Pectoral spine with smooth anterior margin; snout bluntly rounded in lateral view; total vertebrae 52-54 (lower Salween River basin, in western Thailand) ........................................................................................................................... E. salweenensis Pectoral spine with rough anterior margin; snout distinctly pointed in lateral view; total vertebrae 49-51(Indus River drainage in Pakistan; Ganges-Brahmaputra river system in Bangladesh, Bhutan, India and Nepal; Mahanadi River drainage in India; Surma-Meghna river system in Bangladesh) E. vacha

just upstream of Chandpur at Jahasmarachar, $23^{\circ} 15^{\prime} \mathrm{N} \&$ 90³9'E. UMMZ 208444 (1), 117.5mm SL, Bangladesh: Barisal District, Meghna River at Gazipur Char, $22^{\circ} 47^{\prime} \mathrm{N}$ \& 9043'E. UMMZ 237501 (1), 294.6mm SL; Pakistan: Punjab Province, Jhelum River at Jhelum. USNM 165030 (1), 178.2mm SL, Pakistan: Punjab Province, Ravi River at Lahore. Additional data from Ferraris \& Vari (2007).

\section{REFERENCES}

Anganthoibi, N. \& W. Vishwanath (2010). Pseudecheneis koladynae, a new sisorid catfish from Mizoram, India (Teleostei: Siluriformes). Ichthyological Exploration of Freshwaters 21(3): 199-204.

Dishma, M. \& W. Vishwanath (2012). Barilius profundus, a new cyprinid fish (Teleostei: Cyprinidae) from Koladyne basin, India. Journal of Threatened Taxa 4(2): 2363-2369; http://dx.doi. org/10.11609/JoTT.o2838.2363-9
Ferraris, C.J. Jr. (2007). Checklist of catfishes, recent and fossil (Osteichthyes: Siluriformes), and catalogue of siluriform primary types. Zootaxa 1418: 1-628.

Ferraris, C.J., Jr. \& R.P. Vari (2007). Revision of catfishes of the genus Eutropiichthys, with the description of two new species (Siluriformes: Schilbidae). Copeia 2007(4): 866-885; http://dx.doi. org/10.1643/0045-8511(2007)7[866:ROCOTG]2.0.CO;2

Lokeshwor, Y. \& W. Vishwanath (2012).Schistura koladynensis, a new species of loach from the Koladyne basin, Mizoram, India (Teleostei: Nemacheilidae). Ichthyological Exploration of Freshwaters 23(2): 139-145.

Ng, H.H., Lalramliana, S. Lalronunga \& Lalnuntluanga (2013). Pseudolaguvia nubila, a new sisorid catfish (Teleostei: Sisoridae) from northeastern India. Zootaxa 3647(4): 518-526; http://dx.doi. org/10.11646/zootaxa.3647.4.2

Ng, H.H. \& C. Vidthayanon (2011). Pseudeutropius indigens, a new species of schilbeid catfish (Teleostei: Siluriformes) from peninsular Thailand. Zootaxa 3037: 45-50.

Shrestha, J (1981).The Fishes of Nepal. Curriculum Development Centre, Tribhuvan University, Kathmandu. xviii+318 pp. 
Appendix 1. Biometric data for Eutropiichthys cetosus sp. nov. (paratypes).

\begin{tabular}{|c|c|c|c|c|c|}
\hline & $\begin{array}{c}\text { Paratype } \\
\text { PUCMF } 13025 \\
\end{array}$ & $\begin{array}{c}\text { Paratype } \\
\text { PUCMF } 13025 \\
\end{array}$ & $\begin{array}{c}\text { Paratype } \\
\text { PUCMF } 13025 \\
\end{array}$ & $\begin{array}{c}\text { Paratype } \\
\text { PUCMF } 13025\end{array}$ & $\begin{array}{c}\text { Paratype } \\
\text { PUCMF } 13025 \\
\end{array}$ \\
\hline Standard length $(\mathrm{mm})$ & 127.7 & 113.0 & 104.7 & 102.4 & 91.4 \\
\hline \multicolumn{6}{|l|}{$\% S L$} \\
\hline Snout to dorsal-fin origin & 33.8 & 32.4 & 33.9 & 32.4 & 32.9 \\
\hline Snout to anal-fin origin & 46.4 & 47.3 & 46.5 & 45.0 & 48.4 \\
\hline Snout to pelvic-fin insertion & 38.4 & 37.5 & 37.7 & 37 & 37.1 \\
\hline Snout to pectoral-fin spine base & 21.9 & 20.4 & 21.2 & 22.4 & 22.6 \\
\hline Length of dorsal-fin base & 7.4 & 8.1 & 7.2 & 8.0 & 8.6 \\
\hline Dorsal-spine length & 16.8 & 15.5 & 16 & 16.5 & 16.1 \\
\hline Length of anal-fin base & 40.7 & 42.5 & 39.1 & 42.4 & 42.8 \\
\hline Length of first pelvic-fin ray & 7.3 & 7.7 & 9.1 & 9.0 & 8.9 \\
\hline Length of first pectoral-fin ray & 18.3 & 18.2 & 18.9 & 20.7 & 18.4 \\
\hline Length of pectoral-fin spine & 17.6 & 17.1 & 17.2 & 19.7 & 16.7 \\
\hline $\begin{array}{l}\text { Length of dorsal principal caudal- } \\
\text { fin ray }\end{array}$ & 21.5 & 27.3 & 24.5 & 26.0 & 21.8 \\
\hline Body depth at dorsal-fin origin & 19.2 & 22.5 & 22.7 & 19.7 & 23.5 \\
\hline Body depth at anal-fin origin & 20.7 & 22.2 & 22.2 & 17.5 & 23.5 \\
\hline $\begin{array}{l}\text { Body width at pectoral-fin } \\
\text { insertion }\end{array}$ & 11.4 & 12.1 & 10.5 & 11.3 & 12.6 \\
\hline Caudal-peduncle depth & 7.8 & 8.4 & 8.4 & 8.6 & 8.5 \\
\hline Head length & 21.5 & 20.4 & 21.1 & 21.0 & 21.4 \\
\hline \multicolumn{6}{|l|}{$\% \mathrm{HL}$} \\
\hline Head depth & 71.2 & 77.1 & 72.3 & 71.6 & 69.9 \\
\hline Interorbital distance & 28.8 & 29 & 31.2 & 29.3 & 30.6 \\
\hline
\end{tabular}

